\title{
Structural Characteristics of Urban Leisure Sports Space: a GIS Approach
}

\author{
Qian Wang \\ School of Physical Education, Huaiyin Normal University, China
}

\begin{abstract}
Meeting the physical needs of residents is one of the basic functions of the city, the development of sports activities require a certain amount and structure of public sports space. With a case of Wuhan City in China, this paper analyzed the structural characteristics of urban leisure sports space. Results showed that the serving ability of urban leisure sports space in Wuhan City overall was not high, and the serving load was high. Most urban leisure sports space concentrates in city center, and the number of the three categories of urban leisure sports space all declines in the edge. The shortage of block level urban leisure sports space is the key factor for impacting the decision for outside leisure sports. Construction of urban leisure sports space in the future should focus on the outside outlays, in accordance with living space structure, and increase the service efficiency of different levels of urban leisure sports space.
\end{abstract}

KEYWORD: Urban leisure sports space; Spatial structure; Spatial pattern; GIS

\section{INTRODUCTION}

As the material basis of residential physical activities, urban leisure sports space is an important aspect of public service for the government (Pacione, 2013). The National Fitness Ordinance stipulates that the local people's governments at various levels shall guarantee the right of citizens to participate in fitness activities in accordance with the law (Cai et al., 2012). For the development of the national fitness activities, the government needs to do a lot of things, and the first point should be the planning and construction of the urban leisure sports space (Chang et al., 2011). With the advancement of urbanization process, the absence of rational layout and planning of the urban leisure sports space will hinder the implementation of the "National Fitness Plan", and reduce the quality of life of urban residents (Shao, 2012).

Meeting the physical needs of residents is one of the basic functions of the city, the development of sports activities require a certain amount and structure of public sports space (Deforche et al., 2010; Wang et al., 2009). However, seldom studies have been carried out to analyze the structural characteristics of urban leisure sports space. Based on the space-behavior theory, this paper investigated the spatial characteristics of urban leisure space and its exiting problems, using Wuhan as a case study, in order to provide reference and basis for the layout of urban leisure sports space.

\section{MATERIALS AND METHOD}

\subsection{Data source and processing}

Digital data of administrative division at 1:50000 scale and the corresponding population data for each district were provided the local government. Location information for urban leisure sports space was provided by the Sports Bureau of Hubei Province. I imported the location information into ArcGIS 9.3 and then geo-registered it with the administrative division map. According to the National sports facilities survey, public sports facilities are divided into three levels: city level, district level, and block level. We therefore divided urban leisure sports space into three levels.

\subsection{Spatial analysis}

Zonal statistics were applied to summarize the number of urban leisure sports space for each district. Then, Voronoi Graph was one of the most effective approaches to characterize spatial accessibility of public facilities. Voronoi Graph divides the target area into several polygons, within which the traveling distance is the shortest in space. 
I therefore used the proximity analysis function in ArcGIS 9.3 to create the Voronoi Graph. Residents living within the polygon represent those having the shortest distance to urban leisure sports space. Area of these polygons denotes the serving space of urban leisure sports space. Population density in each polygon was also calculated. Then, the load of urban leisure sports space was determined by multiplying the population density, the area of the polygon, and the serving coefficient (1\%o). Buffer analysis was used to analyze the serving scope in space for urban leisure sports space. It should be mentioned that all the spatial analysis was applied for the three categories of urban leisure sports space, respectively.

\section{RESULTS AND DISCUSSION}

\subsection{Spatial locations of urban leisure sports space}

Figure 1 displayed the spatial patterns of urban leisure sports space in Wuhan. Most urban leisure sports space concentrates in city center, and the number of the three categories of urban leisure sports space all declines in the edge. This should be related to the spatial structure of Wuhan City and the "booth pie type" urban expansion towards outside. From the perspective of the dynamic development of urban spatial structure, appropriately increasing the number of urban leisure sports space in the city edge should speed up the population movement from the central core area to the outer layers.

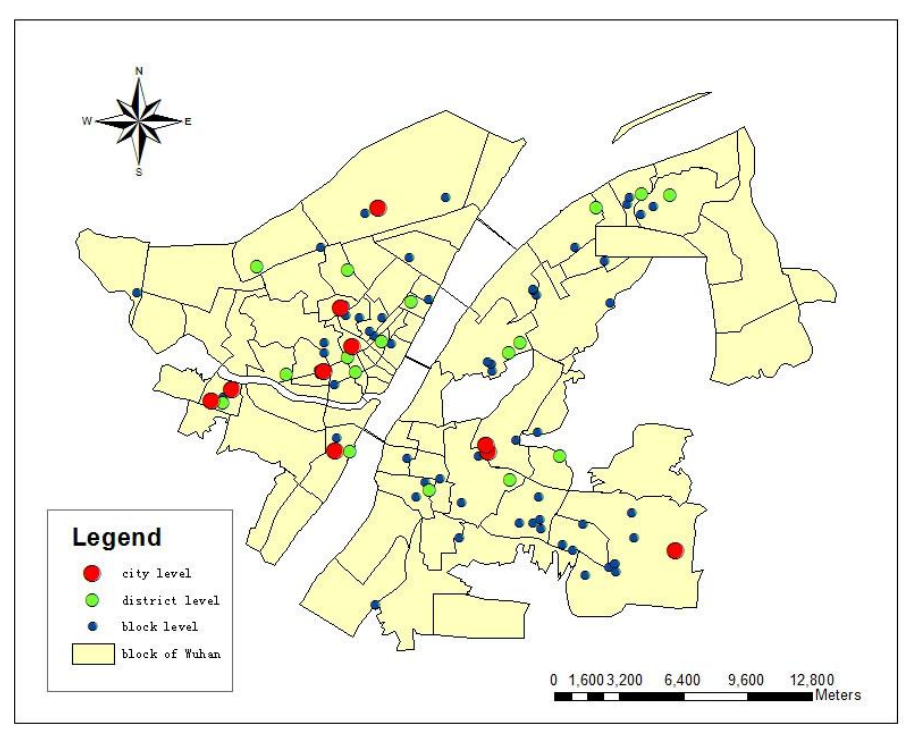

Figure 1. Spatial patterns of urban leisure sports space in Wuhan City, China.

\subsection{Load of urban leisure sports space}

It can be seen from Figure 2 that Qingshan district and Qiaokou district are severely lack of city level urban leisure sports space. Residents in these two districts need to walk long distance to enjoy the service of city level urban leisure sports space. There are two city level urban leisure sports spaces near Zhongnan Road. They have to serve high density residents in three districts. Their serving scope is very big, and the serving load is very heavy. Conversely, there are three city level urban leisure sports spaces in Hanyang district, but their serving scope is relatively small, and the serving load is relatively light.

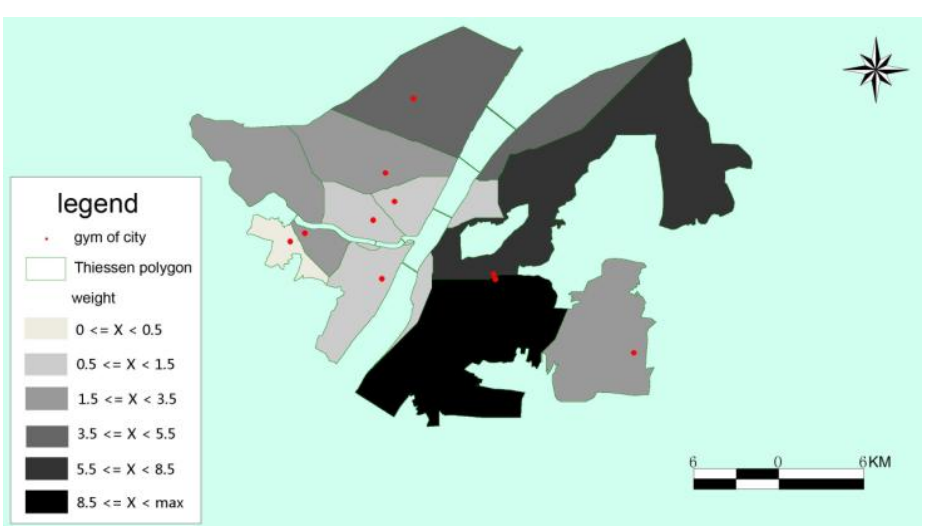

Figure 2. Serving load of the city level urban leisure sports space in Wuhan City.

As shown in Figure 3, the serving load of district level urban leisure sports space is similar to that of city level urban leisure sports space. In particular, the serving load is high for those in the southeastern bank of Yangtze River, and the serving load is low for those in Hangyang district and Qingshan district. Besides, the serving load is relatively high for those in Qiaokou district.

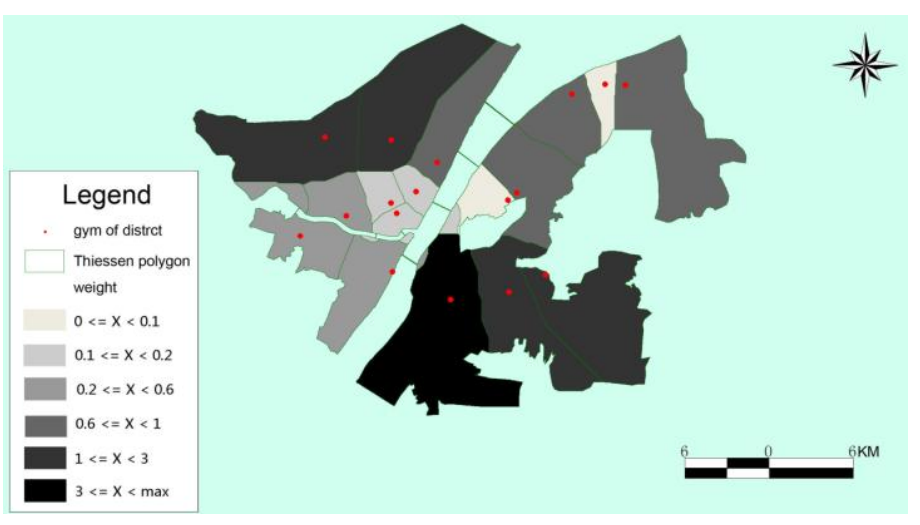

Figure 3. Serving load of the district level urban leisure sports space in Wuhan City.

As shown in Figure 4, the serving load is very heavy for block level urban leisure sports spaces in Qiaokou district. Residents in this district shall walk long distance to enjoy the service of city level urban leisure sports space. Besides, the serving load for most districts in Wuhang is relatively light. It suggests that it would cast relatively less time for residents in these districts to arrive in urban leisure sports spaces. 


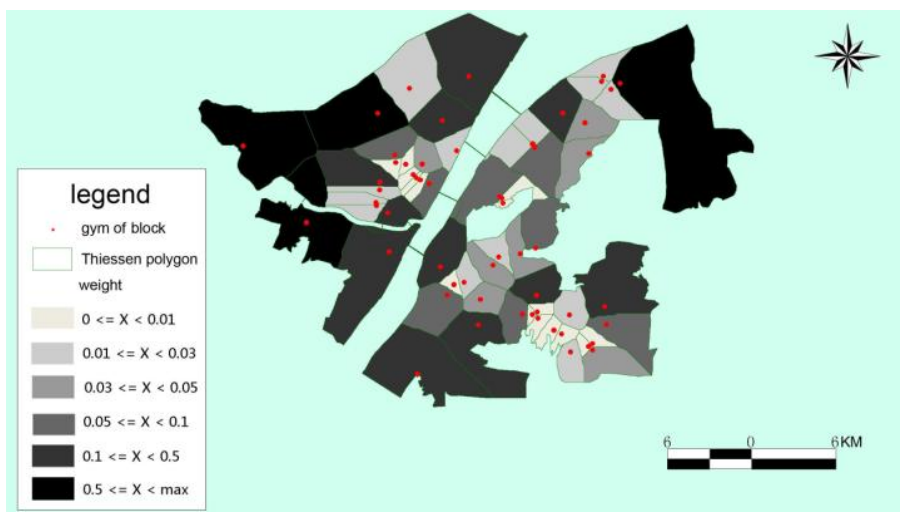

Figure 4. Serving load of the block level urban leisure sports space in Wuhan City.

\subsection{Spatial structures of urban leisure sports space}

The questionnaire survey demonstrated that residents, including those who have cars, are usually to travel for leisure sports when distance exceeds 5 $\mathrm{km}$. Consequently, we set a $5 \mathrm{~km}$ radius buffer for city level urban leisure sports space. Specifically, I divided the $5 \mathrm{~km}$ radius buffer into 10 degrades, and the final multiple buffers were shown in Figure 5. Figure 5 showed that city level urban leisure sports space mainly serve five districts including Jiang'an, Jianghan, Qiaokou, Hanyang, and Wuchang. Conversely, the service of city level urban leisure sports space is very rare for Qingshan district.

The population density in each buffer was further calculated. As shown in Table 1, within the $5 \mathrm{~km}$ radius buffer of city level urban leisure sports space, population density declined from inside to outside, and peaked at 1000-2000 m distance. Besides, only $70 \%$ of the total population can enjoy the service, which implied that the spatial structure of city level urban leisure sports was not rational.

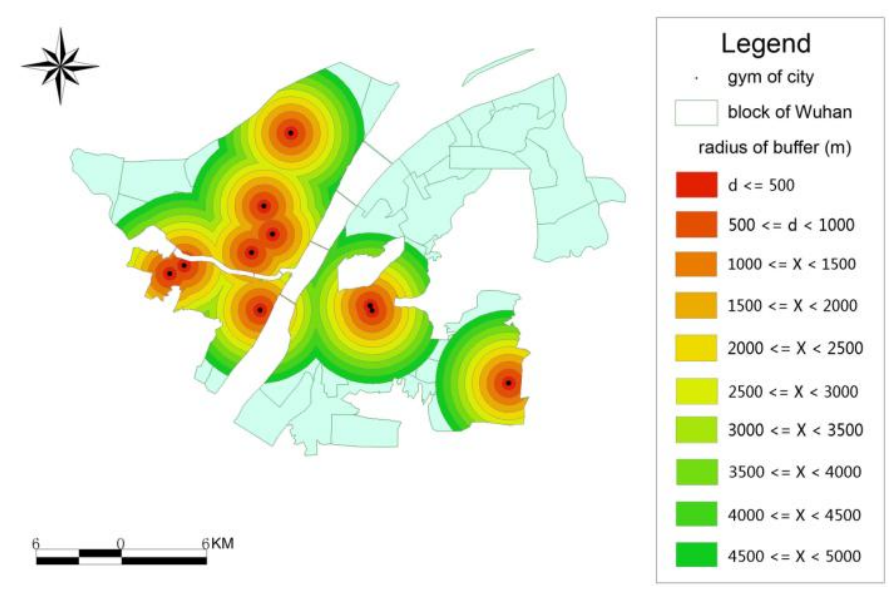

Figure 5. Multiple buffers of the city level urban leisure sports space in Wuhan City.
Table 1 Population density in each buffer zone of city level urban leisure sports space

\begin{tabular}{|c|c|c|c|}
\hline Distance & Area & $\begin{array}{c}\text { Population density } \\
\left(1000 / \mathrm{km}^{2}\right)\end{array}$ & $\begin{array}{c}\text { Percentage in the } \\
\text { total population }(\%)\end{array}$ \\
\hline 500 & 7.3762 & 15.3392 & 2.2056 \\
\hline 1000 & 19.5752 & 17.1527 & 6.5452 \\
\hline 1500 & 25.9995 & 17.5496 & 8.8944 \\
\hline 2000 & 31.1688 & 14.9572 & 9.0877 \\
\hline 2500 & 35.0322 & 12.9998 & 8.8774 \\
\hline 3000 & 34.3438 & 12.3479 & 8.2666 \\
\hline 3500 & 30.3895 & 13.0721 & 7.7437 \\
\hline 4000 & 31.5259 & 13.1670 & 8.0917 \\
\hline 4500 & 29.0538 & 11.7815 & 6.6725 \\
\hline 5000 & 26.0955 & 9.9620 & 5.0675 \\
\hline
\end{tabular}

According to the expert suggestion, we set a 2.5 $\mathrm{km}$ radius buffer for district level urban leisure sports space. Specifically, I divided the $2.5 \mathrm{~km}$ radius buffer into 5 degrades, and the final multiple buffers were shown in Figure 6. Figure 6 showed that district level urban leisure sports space mainly serve three districts including Jianghan, Qiaokou, and Hanyang. Conversely, the service of district level urban leisure sports space is very limited for Wuchang, Hongshan, and Qingshan district.

Table 2 showed the population density in each buffer zone of district level urban leisure sports space. Population density in buffer zones showed similar patter with the living space, declining from inside to outside. Population density was highest within the $500 \mathrm{~m}$ buffer zones. It suggested that district level urban leisure sports space should be built within the $500 \mathrm{~m}$ distance to living space.

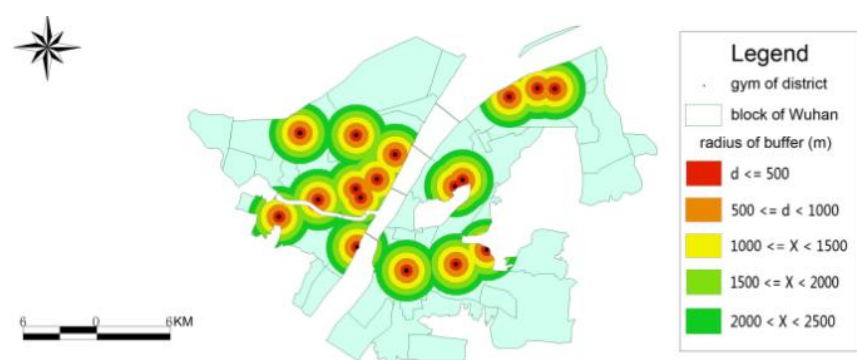

Figure 6. Multiple buffers of the city level urban leisure sports space in Wuhan City.

Table 2 Population density in each buffer zone of district level urban leisure sports space

\begin{tabular}{|c|c|c|c|}
\hline Distance & Area & $\begin{array}{c}\text { Population density } \\
\left(1000 / \mathrm{km}^{2}\right)\end{array}$ & $\begin{array}{c}\text { Percentage in the } \\
\text { total population }(\%)\end{array}$ \\
\hline 500 & 12.3797 & 2.0850 & 8.569912 \\
\hline 1000 & 32.3862 & 1.9731 & 21.21625 \\
\hline 1500 & 45.5190 & 1.7243 & 26.06011 \\
\hline 2000 & 50.7868 & 1.4106 & 23.78574 \\
\hline 2500 & 49.2399 & 1.2458 & 20.36799 \\
\hline
\end{tabular}


According to the expert suggestion, we set a 1.0 $\mathrm{km}$ radius buffer for block level urban leisure sports space. Specifically, I divided the $1.0 \mathrm{~km}$ radius buffer into 2 degrades, and the final multiple buffers were shown in Figure 7. Table 3 showed the population density in each buffer zone of block level urban leisure sports space. Within $1.0 \mathrm{~km}$ distance buffer, it only covers $16.2 \%$ of the total area of the Wuhan City and serves $22.2 \%$ of the total population. Most residents cannot enjoy the service of block level urban leisure sports space. From the practice of the construction of the urban leisure sports space, the current structure of block level urban leisure sports space is not ideal and insufficient. Residents will not go out of their home to take part in leisure sports, because they cannot rely on enough block level urban leisure sports space.

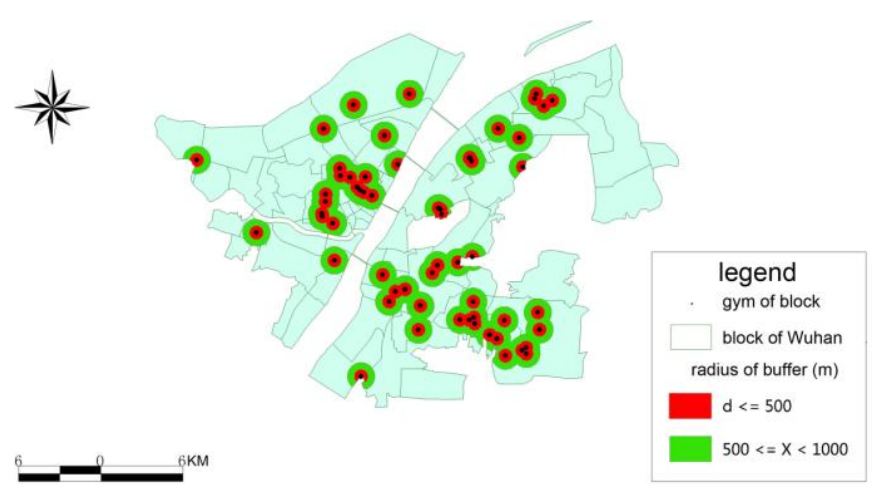

Figure 7. Multiple buffers of the block level urban leisure sports space in Wuhan City.

Table 3 Population density in each buffer zone of block level urban leisure sports space

\begin{tabular}{|c|c|c|c|}
\hline Distance & Area & $\begin{array}{c}\text { Population density } \\
\left(1000 / \mathrm{km}^{2}\right)\end{array}$ & $\begin{array}{c}\text { Percentage in the } \\
\text { total population }(\%)\end{array}$ \\
\hline 500 & 36.995 & 1.6656 & 12.0117 \\
\hline 1000 & 76.2821 & 1.4924 & 22.1922 \\
\hline
\end{tabular}

\section{CONCLUSIONS}

Overall, the serving ability of urban leisure sports space in Wuhan City is not high, and the serving load is high.

(1) Most urban leisure sports space concentrates in city center, and the number of the three categories of urban leisure sports space all declines in the edge.

(2) The serving load of district level urban leisure sports space is similar to that of city level urban leisure sports space. In particular, the serving load is high for those in the southeastern bank of Yangtze
River, and the serving load is low for those in Hangyang district and Qingshan district. The serving load is very heavy for block level urban leisure sports spaces in Qiaokou district.

(3) Within the serving scope of city level urban leisure sports space, population density declined from inside to outside, and peaked at 1000-2000 m distance. Besides, only $70 \%$ of the total population can enjoy the service. Within the serving scope of district level urban leisure sports space, population density in buffer zones showed similar patter with the living space, declining from inside to outside. Population density was highest within the $500 \mathrm{~m}$ buffer zones. Within the serving scope of block level urban leisure sports space, it only covers $16.2 \%$ of the total area of the Wuhan City and serves $22.2 \%$ of the total population.

(4) Construction of urban leisure sports space in the future should focus on the outside outlays, in accordance with living space structure, and increase the service efficiency of different levels of urban leisure sports space.

\section{ACKNOWLEGEMENTS}

This study was supported by the College Philosophy Social Science Fund of Jiangsu Province (2014SJB671), Sports Science Fund of Jiangsu Province Sports Bureau (ST14401203), and the Outstanding Young Talents Support Program of Huaiyi Normal University (36WQ001).

\section{REFERENCES}

[1] Cai, Y. 2012. Study on the structure of urban public sports space. Ph.D thesis of Shanghai Institute of Physical Education.

[2] Cai, Y., Shao, B., Wei, L., Zhu, K., Wang, Y. 2012. Study on present pattern of urban public sports space structure. China Sports Science 32: 9-17.

[3] Chang, N., Qiao, Y. 2011. The reconstruction of urban leisure sports living space in view of social transformation. China Sports Science 31: 14-20.

[4] Pacione, M. 2013. Social Geography: progress and prospect. Taylor \& Francis Press, New York.

[5] Deforche, B., Van Dyck, D., Verloigne, M., De Bourdeaudhuij, I. 2010. Perceived social and physical environmental correlates of physical activity in older adolescents and the moderating effect of self-efficacy. Preventive Medicine 50: S24-S29.

[6] Wang, Q., Su, S., Su, J. 2009. Reconstruction of urban leisure sports space. Journal of Guangzhou Institute of Sports Science 24: 17-22. 